\title{
Sekvensiell kjemoterapi best
}

\section{Kombinasjonsbehandling av \\ lymfeknutepositiv brystkreft bør \\ gis i separate sykluser.}

Kombinert kjemoterapi med antrasykliner og taksaner er gunstig for sykdomsforløp og dødelighet hos kvinner med lymfeknutepositiv brystkreft. Det har hittil vært uvisst om behandlingen bør gis samtidig eller i serie hver for seg.

I en randomisert studie har Swain og medarbeidere sammenliknet 12 ukers samtidig bruk av taksaner i kombinasjon med doksorubicin og cyklofosfamid (ACT) og 24 ukers sekvensiell bruk av de samme cytostatika. Tanken var at samtidig, kortere kombinasjonsbehandling ville ha en synergisk effekt og gi færre bivirkninger. Over 5300 pasienter deltok, og resultatene er nylig publisert (1).

Pasientene som fikk sekvensiell behandling, hadde bedre resultater både når det gjaldt totaloverlevelse og sykdomsfri overlevelse. Kvinner som gjennomgikk cytostatikaindusert menopause, hadde i så henseende om lag $50 \%$ høyere overlevelse uansett behandling.

- Funnet er overraskende, siden det gjaldt både østrogenreseptorpositiv og østrogenreseptornegativ sykdom. Tidligere trodde man dette kun gjaldt hos kvinner med østrogenreseptorpositiv sykdom. Grunnen til at amenoré har gunstig effekt også hos disse, kan være at amenoré gir en individuell indikator på medikamentell toksisitet og dermed er en indikator på økt effekt av cytostatika. Ovarial suppresjon kan også endre det kliniske forløpet av østrogenreseptornegativ sykdom, sier overlege og forsker Mette Kalager ved Kreftregisteret.

- Underveis i studien senket man cytostatikadosene på grunn av fem behandlingsrelaterte dødsfall. Det kan forklare hvorfor effekten av 12 ukers ACT-kur var mindre enn forventet. Det er ingen grunn til å endre dagens retningslinjer i Norge med sekvensiell bruk av taksaner til kvinner med små, lymfeknutepositive svulster, sier Kalager.

\section{Geir Jacobsen}

geir.jacobsen@yale.edu

Tidsskriftet

\section{Litteratur}

1. Swain SM, Jeong JH, Geyer CE jr. et al. Longer therapy, iatrogenic amenorrhea, and survival in early breast cancer. N Engl J Med 2010; 362: $2053-65$

VERDENS HELSE

\section{$\emptyset$ kende forekomst av medfødt syfilis}

\section{Etter mange år med reduksjon \\ i forekomst av syfilis er sykdommen på vei tilbake, særlig i Kina.}

I 2008 ble det født gjennomsnittlig ett barn med syfilis hver time i Kina. For 50 år siden forekom syfilis nesten ikke i Kina, men nå er det den vanligste smittsomme sykdommen i Shanghai (1). Globalt smittes årlig $700000-$ 1,5 millioner barn vertikalt med syfilis. Av disse er ca. $40 \%$ dødfødte eller dør i nyfødtperioden. Medfødt syfilis er dermed vanligere enn f.eks. medfødt hivinfeksjon (2).

I en prospektiv kohortstudie fra Shanghai i Kina fant man 1471 tilfeller av maternell syfilis (298,7 per 100000 levendefødte) og 334 tilfeller av medfødt syfilis 162,4 per 100000 levendefødte) (3). Mødre med lav utdanning hadde dårligst etterlevelse, og risikoen for medfødt syfilis var betydelig høyere ved inkomplett behandling: 50,8\% mot $12,5 \%$. Inkomplett behandling økte også risikoen for dødfødsel $(30,4 \%$ mot $5,5 \%)$, neonatal $d ø d(11,0 \% \operatorname{mot} 0,56 \%)$ og misdannelser $(3,8 \%$ mot $0,46 \%)$.

I en retrospektiv studie fra Haydom-sykehuset i Tanzania beskrives 14 barn med medfødt syfilis (2). Den typiske hudreaksjonen ved sekundær syfilis ble ikke sett hos barn yngre enn én måned, og diagnosen var da vanskelig fordi symptomene liknet neonatal sepsis. Ingen av mødrene hadde vært til syfilisscreeningen som ble tilbudt gravide.

$\emptyset$ kende forekomst av medfødt syfilis er også påvist i i-land. Etter mange år med nedgang økte antall tilfeller i USA fra 8,2 til 10,1 per 100000 levendefødte i perioden 2005-08 (4).

\section{Kristoffer Brodwall}

kristoffer.brodwall@gmail.com

Barneavdelinga

Ålesund sjukehus

\section{Litteratur}

1. Tucker JD, Chen XS, Peeling RW. Syphilis and social upheaval in China. N Engl J Med 2010; 362: 1658-61.

2. Krüger $C$, Malleyeck I. Congenital syphilis: still a serious, under-diagnosed threat for children in resource-poor countries. World J Pediatr 2010 6: $125-31$.

6: $125-31$. syphilis in Shanghai, China, 2002 to 2006. Int $\mathrm{J}$ Infect Dis 2010; e-publisert 6.2.2010.

4. Centers for Disease Control and Prevention Congenital Syphilis - United States, 2003-2008 MMWR Morb Mortal Wkly Rep 2010; 59: 413-7.

\section{Utvikling av svulst på hjernen}

\author{
Ny forskning har identifisert et \\ proteinnettverk assosiert med
} aggressivitet i hjernesvulster.

Høygradige gliomer, som glioblastom og anaplastisk astrocytom, er aggressive svulster i sentralnervesystemet, og de terapeutiske mulighetene er små. I tumorutviklingen konverteres nerveceller til celler som gir en mesenkymal fenotype, noe som gir tumorcellene evne til invasjon og angiogenese. Lite har vært kjent om mekanismene bak denne transformasjonen.

Carro og medarbeidere har nå utført genomvide analyser av høygradige gliomer (1). Kopitallvariasjon alene kunne ikke forklare den mesenkymale fenotypen. Forskningsgruppen benyttet deretter ulike matematiske algoritmer på genuttrykksdata fra 176 høygradige gliomer og identifiserte et nettverk av proteiner som var involvert i aggressiv transformasjon av gliomene. Transkripsjonsfaktorene $\mathrm{C} / \mathrm{EBP} \beta$ og STAT3 viste seg å være essensielle proteiner i dette nettverket.

- Dette er en solid studie. Forskerne har først identifisert de spesifikke transkripsjonsfaktorene som er involvert, og deretter, ved hjelp av cellelinje- og musemodeller, har de verifisert at disse to funksjonelt er sentrale i gliombiologien, sier overlege Petter Brandal ved Oslo universitetssykehus, Radiumhospitalet. - I cellelinjemodeller fant man også at C/EBP og STAT3 var viktige for mesenkymal differensiering og invasivitet. De bekreftet også at høyt uttrykk av proteinene C/EBP og STAT3 i en separat serie med høygradige gliomer var assosiert med dårlig prognose $\mathrm{og}$ mesenkymal fenotype, sier han.

- Det er ingen tvil om at det grundige og veloverveide arbeidet som ligger bak dette manuskriptet, gir oss bedre innsikt i biologien i høygradige gliomer. Likevel bør det nok prospektivt valideres om dette faktisk kan brukes for prognostisering. Det vil på lengre sikt være spesielt interessant å se om man kan bruke denne kunnskapen og disse to transkripsjonsfaktorene som grunnlag for målrettet terapi i høygradige gliomer, sier Brandal.

\section{Åslaug Helland}

aslaug.helland@gmail.com

Tidsskriftet

\section{Litteratur}

Carro MS, Lim WK, Alvarez MJ et al. The transcriptional network for mesenchymal transformation of brain tumours. Nature 2010; 63: 318-25 